Nebojša Zakić ${ }^{1}$

Slavko Božilović

Ivan Šijaković ${ }^{3}$

University "Union - Nikola Tesla",

Belgrade, Serbia
ORIGINAL SCIENTIFIC ARTICLE doi:10.5937/ekonomika1804001Z

Received: November, 04, 2018

Accepted: December, 05, 2018

\title{
ANALYSIS AND UPGRADING OF VALUE CHAIN
}

\begin{abstract}
The contemporary concept of value chains has evolved from many disciplines and directions by creating a complex and multidisciplinary body of knowledge. The value chains consist of structural and dynamic components of a system. The structural components refer to all participants within a chain that, through marketfocused collaboration, execute a sequence of activities that add value. The dynamic components relate to management and relationships among participants, and the ability of the value chain to remain competitive by improving the system. The main activities of a value chain analysis are: end-market analysis, value chain mapping, the analysis of network structure and governance, as well as economic analysis. The results of the analysis are the input for the upgrading strategies. Types of upgrading in value chains are: the upgrading of a product, process, functional and intersectoral upgrading. The paper focuses on the value chains in agribusiness and especially to small agricultural producers.
\end{abstract}

Key words: value chains, value chain components, value chain analysis, value chain upgrading, agribusiness

JEL classification: L16, L23, M11, Q19.

\section{АНАЛИЗА И УНАПРЕЪЕЊЕ ЛАНЦА ВРЕДНОСТИ}

\section{Апстракт}

Савремени концепт ланаца вредности је еволуирао из многих дисииплина и праваца креирајући комплексно и мултидисииплинарно тело знања. Ланце вредности чине структурне и динамичке компоненте система. Структурне компоненте се односе на све учеснике унутар ланца који кроз тржишно фокусирану сарадюу извршавају секвениу активности које додају вредност. Динамичке компоненте се односе на управљање и релације међу учесницима, и способности лания вредности да остане компетитиван унапређујћи систем. Главне активности анализе ланца вредности су: анализа крајњег тржишта, мапирање ланиа вредности, анализа мрежне структуре и структуре управљања, и економска анализа. Резултати анализе су улаз за стратегије унапређења. Типови унапређења у ланцима вредности су: унапређење

\footnotetext{
${ }^{1}$ nebojsa.z@fpb.edu.rs

${ }^{2}$ rektor@unionnikolatesla.edu.rs

${ }^{3}$ sijakovici@gmail.com
} 
производа, проиеса, функционално и интерсекторско унапређење. У раду је нагласак на ланце вредности у агробизнису и посебно на мале пољопривредне произвођаче.

Кључне речи: ланци вредности, компоненте ланцุа вредности, анализа ланца вредности, унапређење ланца вредности, агробизнис

\section{Introduction}

The concept of value chains is a systemic approach that according to Silva \& de Souza Filho (2007) has evolved from many directions, schools and disciplines (economics, management, engineering, operational research, etc.). Evolution of the value chain according to Fasse et al. (2009) has contributed to French filière concept, developed as an analytical tool to explore ways to organise a system of agricultural production in countries under the French colonial system. The Filière concept paid special attention to the fact that local production systems are linked to the processing industry, trade, exports and final consumption.

The term commodity chains originated from the world system theory of Wallerstein, which was later jointly developed by him and Hopkins. According to these authors, commodity chains are understood as a network of working and production processes whose end result is delivered goods (Hopkins \& Wallerstein, 1986). Raikes et al. (2000) state that the contribution of this concept was what served as the basis for the development of a global supply chain, whose main representative is Gereffi with a number of other authors.

During the eighties and nineties, a process approach was developed that involved systematic defining and managing processes, as well as their interaction, in order to achieve the desired results (ISO 9001: 2015). According to one of the definitions (Melan, 1992), the process is viewed as a limited set of interrelated activities that provides a higher value output than the input through one or more transformations. At the same time, the concept of supply chain management was being developed, which included managing the total product flows, as well as the flows of information and money between participants (Buddress, 2014). The focus of supply chains is to integrate the process of producers and suppliers, improve efficiency and reduce losses (Pessoa \& Trababo, 2017).

Porter (1985) develops the concept of value chains arguing that the value for customers is accumulated along the chain of activities all the way to the final product or service. Porter identifies two types of activities: (1) primary activities - directly contribute to adding value to a product or service, and (2) support activities - have an indirect effect on the product or service. Shank \& Govindarajan (1993) represent a value chain observing the company as a part of the overall chain of processes that create value for the customer/user. Value chains begin with suppliers processes that create value by providing basic raw materials and components, proceed with the processes that create value for different classes of customers and sellers all the way to the end consumer, and end with the processes of removal and further recycling of materials. Value creation is observed from the point of view of the chain as a whole, including value chains of related entities (Walas-Trebacz, 2018). 
Gereffi (1994) develops the concept of global commodity chains as interorganisational networks linked to international markets. The author observes four dimensions of the model: (1) the input-output structure, (2) the covered territory, (3) the institutional aspect, and (4) the management structure. The input-output structure and the covered territory are used in the description of the organisational and territorial division of labour and values, and the institutional aspect sets the scene by defining global market conditions (Gibbon, 2001). A crucial dimension is the governance structure that relates to power relations, institutional mechanisms and interorganisational relationships.

The approach of global value chains was the natural development of previous concepts and models. According to Sturgeon (2009), regional, national and local value chains are embedded in the same approach, that is, the approach is equally good for all spatial scales. Value chains have evolved from globalisation, crossed the continental boundaries and became very complex. The concept of global value chains can be associated with increased fragmentation of production across multiple countries, the specialisation of countries in tasks and business functions and the role of networks, global suppliers and global customers (Backer \& Miroudot, 2013).

\section{Value chain components}

Value chains are defined as the full range of activities needed to carry the product from the original concept to the end consumer (Kaplinsky \& Morris, 2001). These activities can be carried out by one company or divided among many participants. Miller $\&$ da Silva (2007) define value chains as a set of participants (private, public, including service providers) and sequences of value-adding activities involved in bringing a product from production to an end consumer.

In agribusiness, value chains can be very complex, including all the processes and actors needed to deliver products and reach consumers. The actors in a value chain in agribusiness are companies that supply farmers with inputs, agricultural producers (small farmers, agricultural organisations), carriers, processors, wholesalers (including exporters and importers), retail organisations, consumers and other stakeholders. Value chains can connect farmers with other participants and end-users in the local environment, across the country, the region or the world (Zakić et al., 2014).

A value chain consists of structural and dynamic components (Dunn, 2012). The structural components of the model include all the companies and other stakeholders involved in the value chain and the vertical and horizontal links between them, the end markets whose demand defines the opportunities that are driven by the value chain, the support markets that offer products and services to support business functions through the value chain and the environment that enables the business within which participants act.

The term end-market indicates where the final transactions in a value chain are made. End markets can be local, national, regional and global. An agricultural product can be sold at a rural market; in city centres in retail chain stores that have purchased a product from local retailers; in neighbouring countries in regional retail chains that have purchased the product from the exporter; or in distant foreign markets in global retail chains. The end markets provide opportunities and a set of parameters for economic growth, determine the characteristics of final products, and end-market demands induce quality and standards. 
Lazarini et al. (2001) introduce the concept of a network chain that is established as a set of networks that consist of horizontal connections between firms within a particular industry, in such a way that these networks or levels are sequentially arranged based on vertical links between firms at different levels.

Vertical links connect companies at different levels of a value chain from input suppliers and manufacturers, to retail organisations and end users. Vertical links also represent the means of the transfer of learning, information, as well as business, financial and technical services from one company to another along a value chain. The ability of a company within the industry to supply customers with a product or provide services that meet all customer requirements depends on the ability of the chain to provide information, knowledge and skills, resources and benefits to all stakeholders in the value chain.

Horizontal links in a value chain are long-term cooperative arrangements among firms that include interdependence, trust and resource sharing in order to achieve common goals. With the evolution of cooperative arrangements, horizontal links are becoming more and more important (Sumner et al., 2013). Horizontal links can help reduce transaction costs, create economies of scale, contribute to the growth of the efficiency of the industry, enable sharing of knowledge, skills and resources, encourage collective learning, improve product and service quality, facilitate risk sharing while increasing the potential for innovation (USAID, 2009a).

Support markets include firms and other organisations that provide products and services to all stakeholders involved in the value chain. Support markets include sectorspecific markets (e.g. supply of specialised equipment), different types of business services (e.g. consultants), financial services (e.g. loans) and information technology (e.g. an information system that provides access to market information).

The business environment consists of all formal and informal rules that define the context within which decisions are made (Dunn, 2012). The business environment consists of many elements: laws, policies, national and international standards, international trade arrangements, norms and customs, business culture and local expectations, etc. Business environments can be local, regional, national or global.

Dynamic elements of a value chain correspond to the developmental features of the market system. Various core processes from the input of raw materials to the final consumption of end products can be identified in the value chain. The core processes will vary depending on the characteristics of the chain being analysed. Power issues in relationships between value chain companies shape intentions that lead behaviour and affect the benefits that businesses have from participating in the chain. Companylevel upgrading indicate what companies do to increase competitiveness through product development, the process of redesigning, market position improvement, and so on. Learning and innovation are the key to creating and maintaining competitive advantage.

According to Dunn (2012), among the dynamic elements with important implications for the implementation of a value chain, the following are distinguished: value chain management, relationships between enterprises and upgradings.

Value chain management refers to the power and ability to realise control along the chain. Gereffi et al. (2005) introduce the typology of the global value chain governance structures based on three factors: (1) the complexity of transactions, (2) the codification of information, and (3) the ability of the supplier. Depending on whether these factors are high or low, in practice, five types of value chain governance have been identified (Gereffi et al., 2005): 
- Market - includes transactions that are relatively simple; information about product specifications is easy to transfer and manufacturers are able to realise products with minimal input of buyers. The price is the central governance mechanism.

- Modular value chains - the product requires chain companies to undertake complex transactions that are relatively easy to codify. It is common for suppliers in these chains to realise products according to customers' preferences (Sturgeon \& Gereffi, 2008).

- Relational value chains - buyer-seller interactions are based on mutual reliance, which is regulated through reputation, social closeness, spatial proximity, and the like. Interactions are complex, making the need to increase explicit coordination.

- Captive value chains - small suppliers are dependent on large, dominant customers and face significant replacement costs in the event of a change in customers. In these networks there is a high degree of power and control of leading companies.

- Hierarchy - characterised by vertical integration and management control within the company that independently realises its products. This is usually the case where product specifications cannot be codified, products are complex or competent suppliers cannot be found.

Relations among stakeholders in a value chain that support the chain competitiveness (and healthy competition) are mutually co-operative and allow free information transfer and incentives to improve. Horizontal co-operation can include formal and informal arrangements. Formal organisations of members provide services that include collective production and marketing activities, as well as supply of input components, financial services, technology, education, shared resources management. There are various forms of these formal organisational arrangements including co-operatives, associations and clusters.

Vertical cooperation refers to the methods of linking that coordinate all stages from production to sale (Frank \& Henderson, 1992). On the continuum from market exchange to complete vertical integration, the mechanisms of vertical co-operation can take different forms. Vertical cooperation offers many benefits by enabling the transfer of learning, information and services among firms along the chain. Small farmers are vertically connected to a wide range of market participants. The nature of vertical links often determines the benefits of distribution along the value chain and creates stimuli or limitations for improvements and innovations.

From the perspective of small agricultural producers, various forms of co-operation can bring many benefits, including greater control over production, cost savings, strengthening their negotiating position, developing knowledge (from production, marketing, etc.), improving social capital, and so on. (Balint, 2004; de Roest et al., 2018, Rivera et al., 2018).

Company-level upgrading refers to the changes that participants in a value chain make to enhance their competitiveness. Upgradings require access to information/ knowledge, technology and finance. Investments are necessary to increase added value. Improving and developing products, processes, marketing and organisations are a 
foundation for maintaining competitiveness, enabling businesses to satisfy the market by introducing innovations. For participants in the value chain, it is essential that learning and innovation flow through a value chain in order to optimise returns on investment. Learning and innovating in a systemic sense are closely related to stimuli that encourage or discourage the transmission and absorption of new knowledge and skills, and the types of mechanisms that are established to influence their transfer.

\section{Value chain analysis}

Value chain analysis is a process for understanding the system factors and the conditions under which the value chain and participants in the chain can achieve a higher level of performance (USAID, 2009b). The purpose of the value chain analysis is to better understand the system and identify strategies for improvement (Stein \& Barron, 2017).

There are many ways to analyse and evaluate value chains, as well as different levels of value chain analysis from micro to global levels (Gereffi \& Kaplinsky, 2001). The analysis may result from the research of secondary information, such as data from governments, statistical institutes and business branches, or from field research by different participants through interviews and questionnaires. The data can also be derived from participatory market assessments and market observations. The analysis requires the mapping of a value chain, various detailed research and analysis, checking findings with stakeholders, and recommendations for future actions. Results of the value chain analysis serve to establish a vision and strategy for upgrading. The analysis uses a number of tools and techniques that can help in the diagnosis of conditions, interpretation of data and taking further steps.

Value chain analysis has become a part of more robust projects and models of value chain development initiatives designed to intervene in markets so as to create conditions that are more suitable for small farmers. These models are often created by global and national organisations (UNIDO, ILO, USAID, GIZ/GTZ, etc.) The inclusion of small-scale farmers in value chains provides opportunities for access to larger and richer markets, greater stability and income security (a stable market and predetermined prices), better access to inputs, increased productivity and overall revenue growth. However, there are limitations that limit the competitiveness of small farmers and prevent them from participating in value chains (Fernandez-Stark \& Banber, 2012). Larger and richer markets are looking for much more in terms of business knowledge, efficiency, quality standards and security than local markets. In order to participate in these markets it is necessary for small farmers to carry out regular deliveries of products of the required quality and quantity which requires the access to land, inputs, technology, knowledge, organisation, capacity, and infrastructure that may be missing from some groups of small farmers (Devaux, 2017).

The value chain analysis consists of the series of different methods. An endmarket analysis and value chain mapping are essential methods based on which further qualitative and quantitative analyses follow. After constructing maps (diagrams) of chains, their quantification is carried out, the static and dynamic components of the chain are researched and analysed. Depending on the goals and needs of the analysis, it can 
be very complex, including various specialised studies. A value chain analysis can be understood as an iterative process. The need for a deeper analysis in a certain segment (in the next iteration) is often created as new ideas and requirements are created based on the previous analyses. One of the most demanding segments of analysis involves an analysis of economic performance.

The end markets are the starting point for analysing a value chain. Identifying market potential and specific market opportunities are basic tasks in every marketoriented approach. The analysis examines each existing or potential market to determine what is needed to compete in that market and what benefits and risks can be expected for each participant in the chain. Thr key elements of the research are (GTZ, 2007; UNIDO, 2009): market specificities and marketing opportunities for identified products - demand for certain types of products, size and market dynamics, seasonal consumption, prices and customer requirements; competitors that exist on the market - data on competitors, their products, links in global value chains, factors of competitive advantage; prevailing conditions in terms of market access - existing physical infrastructure (communications, roads, warehouses, logistics, etc.), distribution channels, the power of market participants, standards, customs and non-tariff barriers, etc.

The value chain as a whole depends on the end market and the consumer, and therefore a deep understanding of the end market is in the interest of all stakeholders involved in the value chain. Since markets are dynamic, it is also necessary to identify trends in these markets (Campbell \& Downing, 2008).

Mapping a value chain is creating a visual presentation of connections between business entities in the chain, including other market players (Herr \& Muzirra, 2009). Mapping is a fundamental part of the analysis, because it is very difficult to see relevant interdependencies or discuss opportunities for improvement without a visual presentation. According to Herr \& Muzzira (2009), mapping has the following implications: it allows to illustrate and understand the flow of product movements through different stages to end consumer; serves to identify and categorise major market players in the chain; illustrates which support organisations are available and at what levels of the chain they concentrate their services; shows various market channels through which products and services reach the end customer; help companies to orient their activities, identify actors, supply channels, competitors, the weak links in the chain, and so on.

The output of the mapping process is many diagrams, which differ in accordance with their purpose (the diagram of the core processes, flows among actors, a network diagram illustrating different market channels, etc.). It is crucial to achieve the right degree of detail that provides enough information to make the diagram useful, but it is still easy to understand. After creating the necessary diagrams, the focus is on their quantification. Quantification depends largely on the availability and reliability of secondary data, especially statistical ones.

The analysis of a network structure and dynamic components of a value chain, primarily the form of governance and relations, is possible after mapping value chains. Network structure analysis differentiates horizontal and vertical links, emphasising that agents are interconnected to one another at the same level (horizontal connections) and with agents at other levels (vertical links). The qualitative analysis of vertical links includes a description of vertical links, the amount and quality of information and services that flow through different vertical links, the identification of weak or missing vertical 
links, and so on. An analysis of horizontal links involves the description and purpose of these links, the balance between co-operation and competition, the identification of missing or inappropriate horizontal links, the level of trust between members performing similar functions, it can indicate the areas where negotiating power of small participants in the chain can increase, etc.

The structure of a network depends largely on the market channels chosen by different participants. Channel choices can be very limited by market access limits, such as supporting infrastructure to reach the market, the access to information (on demand, prices, fluctuations, etc.) and specific market demands, such as production in accordance with quality and safety standards. The ability of small farmers, entrepreneurs and companies to take part in market channels is closely related to market characteristics, the knowledge of the requirements and technological abilities of the producers (Trienekens, 2011).

Analyzing relationships among actors involves an analysis of co-operation and competence. Both of these categories can be effective or ineffective in different contexts. Co-operation is effective when actors can quickly identify and work together to meet important common interests. On the other hand, co-operation is ineffective when actors agree to achieve monopolistic control. Competition is effective when rivalries lead to improvement and innovation, on the contrary, competition is ineffective when it is based on price (rather than productivity), when one negotiator wants to achieve everything (at the expense of others), and so on. The relationship analysis should determine the extent to which existing relationships encourage learning and innovation, the degree of (non) confidence among participants, the motivation for establishing relationships, and others (USAID, 2009a).

Regarding the support market, the analysis should identify the possibilities for better access to services for the target audience in the value chain. The analysis includes a description of the service provided by the participants in the chain or by external entities, the identification of the restrictions for the provision of services, and the restriction of access to services to the participant in the value chain, the missing or the poor service to the participants in the chain, which significantly affects competitiveness.

The previous section lists the types of global value chain governance. The forms of governance can be changed as an economic branch evolves and matures, and the management patterns within a branch can vary according to the stage of the chain. According to Sturgeon (2009), power in the chain is a crucial issue in terms of value chain governance. The two basic types of companies within the chain are the leading companies and suppliers. Leading firms can be manufacturers or customers with little or no own production. Because they have ways to choose and change suppliers, these companies have the purchasing power. This power allows the leading company to explicitly coordinate chain activities and pressure suppliers to reduce costs, improve quality, apply specific processes, procure from certain suppliers, etc.

The second category is the power of suppliers. An extreme form of this power is a platform leadership where market and technological domination allows leaders to establish standards (for example, Intel). The more common in value chains is the softer form of power - the power of competence, arising from technical, service and other abilities that are rare, valuable and difficult to change and imitate (Palpaucer, 2000). Suppliers have the power of competence when their products and services are 
seen as essential to the leading companies they serve. However, leading firms can use their purchasing power to limit the power of suppliers, as even the most competent and important suppliers base their success on future orders.

A part of the power in a value chain is shared by other stakeholders, such as government institutions and other involved stakeholders. Different authors emphasise the importance of the influence of institutions on value chains (Daviron \& Ponte, 2005; Sturgeon, 2009). Institutions include the regulatory mechanisms of national states, but also intergovernmental institutions, such as the European Union and the World Trade Organisation. Some of the effects that global institutions have on global value chains can be related to the degree to which participants in developing countries can benefit from a value chain (Bair, 2005), or global agreements can affect participants so that certain participants, for example producers, get into a weaker position (Daviron \& Ponte, 2005).

The analysis of economic performance and benchmarking of the competitors allows a value chain to position itself appropriately against the competitors, identify strategic and non-strategic activities, raise the awareness of the participants in the chain in relation to cost drivers, margins for price negotiations and value-added opportunities, and recommend appropriate actions. This analysis includes the analysis of the external environment and the analysis of economic parameters (UNIDO, 2009). The environmental analysis consists of: economic and social environment analysis - basic economic data on land, exports and imports, economic policy, government measures for the promotion and financing of industry; industrial environment analysis - affects the resulting value chain and competitors including various institutions and agencies (standardisation, certification, accreditation, metrology, consulting, etc.), and technological environment analysis including technical support systems that allow participants to acquire technologies, equipment, and production procedures, as well as exploit technological know-how.

The analysis of economic parameters includes: the analysis of production costs, value added analysis and benchmarking performance. The calculation of production costs in a value chain implies (GTZ, 2007): the aggregation of costs incurred by enterprises in each segment of the chain and linking data with functions in the value chain (here it is not about an enterprise, but a sequence of production, marketing and other operations within the value chain). This analysis is used to identify cost drivers at different stages of the chain and the potential to reduce costs. Added value represents the value generated during the production process. In order to achieve the added value generated by a specific chain, the costs of the purchased material, components and services must be deducted from the sales value. Benchmarking of a value chain is important, because it serves to evaluate the position of the value chain in relation to competitors. The key parameters used for comparison are unit costs of production, productivity, quality of the process, etc.

Calculating economic parameters is very complex. Different problems can arise in the analysis, especially in micro, small and medium-sized enterprises in terms of reliability, availability, regularity and homogeneity of accounting data. Therefore, this analysis is often based on cost estimates that must be carefully checked. Benchmarking analysis is also challenging in terms of data that are difficult to obtain. Solutions can be the engagement of experts for a particular industry or allowing the access to specialised data. 


\section{Value chain upgrading}

Growth and international competitiveness depend on the ability of society to improve businesses and industries. Upgrading refers to shifting from lower-value economic activities to those higher values within global value chains using local innovation capabilities to make improvements in processes, products, and functions (McDermott, 2005). Among the upgrading paths that farmers can choose from, there are quality upgrading, more efficient production, product and process innovation, non-technological innovations, horizontal cooperation (co-operatives, associations), the acquisition of certification schemes, reaching new markets, learning from leading companies through partnerships, etc.

Upgrading places a strong emphasis on innovation (technological and nontechnological). Innovation is viewed in a relative context, how many actors innovate in comparison to competition. If the innovation rate is lower than the competitors' one, this results in a reduction in added value and market share (Kaplinsky \& Morris, 2001). Therefore, in the context of global value chains, the upgrading is defined as innovation to increase added value (Giuliani et al., 2005).

According to Humphrey \& Schmitz (2002), four types of upgrading were identified in value chains:

- Process upgrading, more efficient transformation of inputs into outputs by reorganisation of production systems or introduction of superior technology.

- $\quad$ Product upgrading, moving to more sophisticated production lines in terms of increasing unit value.

- Functional upgrading, the acquisition of new superior functions in the chain, and the increase in overall skill content or abandoning low value added functions to focus on those with higher added value.

- Intersectoral upgrading, the application of competencies acquired in a specific sector and moving horizontally to another sector.

Upgrading processes and products are the most common elements of success in value chains in developing countries, and this strongly contributes to exports. Usually it is started by process upgrading, followed by product upgrading, but there is no need to cease there. Functional and intersectoral upgradings enable businesses and countries to move towards activities and sectors with more added value. However, these upgradings are rarely occurring in developing countries, as manufacturers and other participants in these countries are mainly suppliers for partners in the chain of developed countries. This may mean that domestic businesses in developing countries only play a peripheral role within global value chains, while more value-added activities are controlled by the leading companies in the chain, multinational companies (McDermot \& Corredoira, 2010).

Pananond (2015) points out that the strategic option for successful domestic businesses to move towards more value-added activities is that they also embark on the international arena. Domestic companies in manufacturing, trade and services should consider international expansion as part of their advancement trajectory. International expansion is becoming an essential alternative to overcoming the peripheral roles and constraints established by leading companies in global chains. Internationalisation and innovation are highly integrated strategic activities, innovations have direct effects on internationalisation, and the exit beyond local and national borders increases the need for innovation (Filippeti et al., 2013, Vukajlović \& Ćurčić, 2016; Lamote \& Colovic, 2018). 
Trienekens (2011) also adds the upgrading of the network structure and management structure of a value chain. These upgradings relate to finding markets that offer opportunities for increasing added value and enhancing organisational arrangements that enable chains to create and take value from the market for different stakeholders in the chain. Here is an emphasis on non-technological innovations (organisational and social innovations and marketing innovations).

According to Stamm \& von Drachenfels (2011), vertical value chain interventions tend to strengthen the dialogue between large enterprises that dominate a value chain and smaller businesses and entrepreneurs to identify opportunities for increasing participation in the value chain of small, local actors. Vertical relations in chains are often enhanced by transaction-specific investments of processors or retail chains and exporters in order to reduce the uncertainty of delivery and increase the quality and consistency of suppliers.

Horizontal value chain interventions focus on the access to technical, business and financial services, so that small farmers can more effectively participate in national, regional and global value chains, as well as on collective actions of participants (Stamm \& von Drachenfels, 2011). Horizontal partner co-operation significantly improves the value chain. Small participants in a value chain (farmers, entrepreneurs, small businesses) can use complementary competencies, knowledge sharing, technologies and inputs, develop greater responsiveness to end-market requirements and achieve higher export levels as a result of horizontal co-operation. Lu et al. (2008) find that the crucial role for small farmers lies in social capital in the management of business transactions and the pursuit of marketing strategies (emphasising the importance of interpersonal confidence), achieving long-term business relationships and strengthening their negotiating power.

\section{Conclusion}

Systemic approach sees value chains as systems with many activities and actors. A complex and multidisciplinary body of knowledge about value chains has evolved from many disciplines and directions (economics, management, engineering, operational research, etc.). Value chains are defined as a full range of activities that can be done by one company or divided among many different participants needed to carry the product from the original concept to an end consumer. Value chains in agribusiness are made up of a variety of different actors and processes that add value, carrying a product from production to the end consumer.

The conceptual value chain model includes structural and dynamic components of the system. This model is the basis for value chains analysis. Structural components are made by all the participants involved in a value chain, their horizontal and vertical links, the support markets and the business environment. Dynamic chain components are associated with the changing characteristics of the market system, including building the relationships between companies, the value chain management, and the implementation of promotion activities.

Value chain analysis is the process of linking the chain to its constituent parts in order to better understand its structure and functioning and identify strategies for improvement. The value chain analysis requires, inter alia, the research and analysis of the end-market, mapping the value chain, identifying participants at each chain level and identifying their functions and relationships (network structure), determining the structure of management and leadership in the chain, the economic analysis involving the identification of activities that add value 
and allocating costs and determining the added value for each activity and benchmarking the competitors. Depending on the goals and needs of the analysis, the analysis can be very complex, including various specialised analyses and studies. In agribusiness, analysis can focus on individual actors, especially small agriculture producers, whose inclusion in value chains can significantly contribute to increasing their income and strengthening the competitive position.

By enhancing economic activity of lower values, they move towards higher value activities within value chains using local innovative capacities. Types of improvement in value chains are: product improvement, process, functional and intersectoral improvement. Improving processes and products are the most common elements of success in value chains in developing countries. However, it is necessary to go further with improvements, so that domestic companies and participants would not play a peripheral role in global value chains, which involves focusing on functions and activities with higher added value and international expansion.

\section{Reference}

Backer, K., \& Miroudot, S. (2013). Mapping Global Value Chains. OECD Paper No. 159. Paris, France: OECD.

Bair, J. (2005). Commodity Chains: Genealogy and Review. In: J. Bair (ed.) Frontiers of Commodity Chain Research. Palo Alto, US: Stanford University Press.

Balint, B. (2004). Institutional factors influencing agricultural sales of the individual farmers in Romania. In: M. Petrick, P. Weingarten (eds.). The role of agriculture in central and eastern European rural development: Engine of change or social baffer? Halle, Germany: IAMO, 238-256.

Buddress, L. (2014). Integration: Supply chain view. Strategic Management: International Journal of Strategic Management and Decision Support Systems in Strategic Management. 19(3), 3-9.

da Silva, C. A., \& de Souza Filho, H. M. (2007). Guidelines for rapid appraisals of agrifood chain performance in developing countries. Rome, Italy: Food and Agriculture Organization of the United Nations.

Daviron, B, \& Ponte, S. (2005). The Coffee Paradox. London, Great Britain: Zed Books.

De Roest, K., Ferrari, P., \& Knickel, K. (2018). Specialisation and economices of scale or diversification and economies of scope? Assesing different agricultural development pathways. Journal of Rural Studies, 59, 223-231.

Devaux, A. (2011). Agricultural innovation and inclusive value-chain development: a review. Journal of Agribusiness in Developing and Emerging Economies, 8(1), 99-123.

Dunn, E. G. (2012). Facilitating systemic change in value chains: lessons learned for strenghtening country system. Washington DC, US: USAID.

Fasse, A., Grote, U., \& Winter, E. (2009). Value chain analysis: Methodologies in context of environment and trade research. Hannover Economic Papers.Hannover, Germany: Leibniz Universitat. 
Fernandez-Stark, K. \& Bamber, P. (2013). Inclusion of Small and Medium Producers in the Value Chain. Durham, US: Duke Global Value Chain Centres.

Filippeti, A., Frenz, M., Ietto-Gilies, G. (2013). The role of internationaliyation as a determinant of innovation performance. An analysis of 42 countries. CIMR Research Working Paper Series. London, UK: Birkbeck Univerisity of London.

Frank, S. D. \& Henderson, D. R. (1992). Transaction costs as determinant of vertical coordination in the U.S. food industries. American Journal of Agricultural Economics, 74(4), 941-950.

Gereffi, G., \& Kaplinsky, R. (2001). The Value of Value Chains: Spreading the Gains from Globalisation. IDS Bulletin, 32(3).

Gereffi, G. (1994). The Organisation of Buyer-driven Global Commodity chains: How US Retailers Shape Overseas Production Networks. In G. Gereffi \& M. Korniewicz (eds.). Commodity chains and Global Capitalism. Westport, US: Praeger, 95-122.

Gereffi, G., Humphrey, J., \& Sturgeon, T. (2005). The governance of Global Value Chains. Review of international Political Economy, 12(1), 78-104.

Gibbon, P. (2001). Upgrading Primary Production: A Global Commodity Chain Approach. World Development, 29(2), 345-363.

Giuliani, E., Pietrobelli, C., \& Rabelotti, R. (2005). Upgrading in Global Value Chains: Lessons from Latin American Clusters. World Development, 33(4), 549-573.

GTZ (2007). ValueLinks Manual. Eschborn, Germany: Deutsche Gesellschaft für Technische Zusammenarbeit.

Herr, M. L. \& Muzira, T. J. (2009). Value chain development for decent work. Geneve: International Labour Office (ILO).

Hopkins, T., Wallerstein, I. (1986). Commodity chains in the world economy prior to 1800. Review (Fernard Brauder Center), 10(1), 157-170.

Kaplinsky, R., Morris, M. (2001). A Handbook for Value Chain Research. Otava, Canada: International Development Research Center.

Lamotte, O. \& Colovic, A. (2013). Innovation and internalization of young entrepreneurial firms. Le Management International entre local and global, 18(3), 87-103.

Lazarini S. G., Chaddad F. R., \& M. L. Cook (2001). Integrating Supply Chain and Network Analysis: The Study of Netchains. Journal on Chain and Network Science 1(1): 7-22.

Lu, H., Trienekens, J., Omta, O., Feng, S. (2008). The role of guanxi networks and contract in Chinese vegetable supply chains. Journal on Chain and Network Science, 7(2), 121-131.

McDermot, G. A. \& Corredoira, R. A. (2010). Network composition, collaborative ties, and upgrading in emerging market firms: lessons from the Argentine autoparts sector. Journal of International Business Studies, 41, 38-29.

McDermott, G. A. (2005). The Politics of Institutional Renovation and Competitive Upgrading: Lessons from the Transformation of the Argentine Wine Industry. William Davidson Institute Paper Number 817. 
Melan, E. H. (1992). Proces Management: Methods for improving products and service.New York, US: McGraw-Hill.

Miller, C., da Silva, C. (2007). Value chain financing in agriculture. Enterprise development and microfinance, 18(2-3), 95-108.

Palpaucer, F. (2000). Competence-Based Strategies and Global Production Networks a Discussion of Current Changes and Their Implications for Employment. Competetion and Change 4(4), 1-55.

Pananond, P. (2015). Motives for foreign direct investment: a view from emerging market multinationals. The Multinational Business Review, 23 (1), 77-86.

Pessoa, M. V. P. \& Trabasso, L. G. (2017). The Lean Product Design and Development Journey. Cham, Switzerland: Springer International Publishing.

Porter, M. (1985). Competitive Advantage: Creating and Sustaining Superior Performance. New York, US: Free Press.

Raikes, P. Jensen, M. F., Ponte, S. (2000). Global commodity chain analysis and French filiere approach: comparison and critique. Economy and Society, 29(3), 390-417.

Rivera, M., Knickel, K., Diaz-Puente, J. M., Afonso, A. (2018). The role of social capital in agricultural and rural development: Lessons learnt from case studies in several countries. Sociologia Rurals, June 2018.

Shank, J. K., \& Govindarajan, V. (1993). Strategic cost management. Free Press, US:New York.

SRPS ISO 9001:2015 Sistemi menadžmenta kvalitetom - Zahtevi. Beograd: Institut za standardizaciju Srbije.

Stamm, A. \& von Drachenfels, C. (2011). Value chain development: Approaches and activities by seven UN agencies and opportunities for interagency cooperation. Geneve, Switzerland: Labour Office.

Stein, C., \& Barron, J. (2017). Mapping actors along value chains: Integrating visual network research and participatory statistics into value chain analysis. CGIAR Research Program. Montpellier, France: CGIAR.

Sturgeon, T. J. (2009). From Commodity Chains to Value Chains: Interdisciplinary theory Building in the Age of Globalization. In: J. Bair (ed.) Frontiers of Commodity Chain Research. Stanford, US: Stanford University Press.

Sumner, J., McMurtry, J. J., Renglich, H. (2013). Leveraging the local: Cooperative food systems and the Local organic food co-ops network in Ontario, Canada. Journal of Agriculture, Food Systems and Community Development, 4(3), 47-60.

Trienekens, J. H. (2011). Agricultural Value Chains in Developing Countries A Framework for Analysis. International Food and Agribusiness Management Review. 14 (2), 51-82.

UNIDO (2009). Agro-value chain analysis and development. Vienna, Austria: United Nations Industrial Development Organization.

USAID (2009a). Global food security response. Washington DC, US.

USAID (2009b). Value chain finance: Primer, diagnostic checklists and model scope of work. Washington DC, US. 
Vukajlović, Đ. \& Ćurčić, N. (2016). Ocena faktora konkurentnosti i inovativnosti u cilju ostvarivanja tržišnog učešća. Ekonomija: teorija i praksa, 8(3), 35-54.

Wallas-Trebacz, J. (2018). Efficiency evaluation of the functioning of an enterprise's value chain as a criterion for the choice of a successful strategy of market competition. Ekonomika, 64(2), 9-22.

Zakić, N., Vukotić, S., Cvijanović, D. (2014). Organisational models in agriculture with special reference to small farmers, Economics of Agriculture/Ekonomika poljoprivrede, 61(1), 225-239. 